\title{
Intolerance unveiled? Burkini bans across France
}

Mariëtta D.C. Van der Tol

\section{OpenEdition}

\section{Journals}

Electronic version

URL: http://journals.openedition.org/rdr/338

DOI: $10.4000 /$ rdr.338

ISSN: 2534-7462

\section{Publisher}

Presses universitaires de Strasbourg

\section{Printed version}

Date of publication: 6 November 2018

Number of pages: $139-149$

ISBN: 979-10-344-0023-2

ISSN: 2493-8637

\section{Electronic reference}

Mariëtta D.C. Van der Tol, « Intolerance unveiled? Burkini bans across France », Revue du droit des religions [Online], 6 | 2018, Online since 25 November 2019, connection on 22 November 2020. URL http://journals.openedition.org/rdr/338; DOI : https://doi.org/10.4000/rdr.338

La revue du droit des religions est mise à disposition selon les termes de la Creative Commons Attribution - Pas d'Utilisation Commerciale 4.0 International - CC BY-NC 4.0. 


\section{INTOLERANCE UNVEILED? BURKINI BANS ACROSS FRANCE}

\section{Mariëtta D.C. VAN DER TOL}

PhD student, Cambridge University

\section{RÉSUMÉ}

Cet article examine l'illégalité des décisions d'interdiction du burkini en France du point de vue de la tolérance, analysant les textes juridiques et les expressions politiques des maires par rapport à des facteurs caractéristiques de la tolérance moderne - vérité, bien commun, unité extérieure, paix et ordre publics, confiance. Bien que les juridictions supérieures en France et en Europe aient tendance à défendre la liberté individuelle dans ce type de cas, les tendances locales à l'intolérance qui visent la visibilité de l'altérité dans l'espace public sont profondément préoccupantes. De telles tendances pourraient se traduire par diverses réglementations restrictives qui impliquent de se prémunir contre une régression de la liberté religieuse individuelle.

\section{Abstract}

This paper qualifies the unlawfulness of the 2016 "burkini bans" in France from the perspective of toleration. It asserts that they reveal a tendency towards intolerance, evaluating the legal texts and political expressions of mayors against specific factors of early modern toleration - truth, common good, (outward) unity, public peace and order, and trust. Although higher courts in France and Europe tend to defend individual freedom in this and adjacent types of legal questions, local tendencies towards intolerance which target the visibility of otherness in the open space are profoundly concerning. Such tendencies might translate into variations of restrictive regulations, which indicate need to guard against regression in lieu of (individual) religious freedom. 


\section{INTRODUCTION}

The visibility of religious difference in the shared public and private space has historically been key to levels of toleration and integration. Although the dominant narrative is that early modern toleration has been replaced by a sophisticated legal framework designed around central concerns of individual freedom and values such as laïcité and neutrality, ${ }^{1}$ a growing body of historical literature proposes a less dichotomic interpretation of the relationship between early modern toleration and constitutional religious freedom. The question on the visibility of religion seems to shape the current legal, political, and social debates on the role of religion in French society, particularly with regard to head coverings such as the much contested burkini. In this paper I argue that the numerous "burkini bans" of 2016 revealed several intolerant tendencies - in its historical sense - because of the nature of the arguments advanced in the local arrêtés and the general focus on the visual aspect of the burkini as a sign of (radical) Islam.

This paper opens with a section on religious freedom and toleration, and presents a number of historically important factors surrounding toleration and the restriction thereof. These factors are presented as an assessment framework. The paper will then analyze the legal and political arguments made in the local arrêtés, comparing them with the factors of toleration. For if it is true that early modern toleration has shaped modern and constitutionalized religious freedom, one would expect to observe some resonances with the factors of toleration in contemporary legal-political cases on religious freedom. Whereas not all aspects of the factors of toleration are necessarily incompatible with the functioning of state bodies, these might enter into conflict with the imperative of neutrality and impartiality. Therefore, this paper concludes with some critical reflections regarding neutrality and laicité in conversation with the framework of toleration, particularly with regard to the visibility of difference and the value of protecting individual freedom.

1. H. van Ooljen, Religious Symbols in Public Functions, Cambridge, Intersentia 2012, p. 163 175. 


\section{THEORETICAL FRAMEWORK: TOLERATION AND CONSTITUTIONAL RELIGIOUS FREEDOM}

Toleration and religious freedom are not each other's conceptual equivalents. Toleration in early modern contexts (ca. 1500-1789) entailed a governmental technique in regulating diversity after the disintegration and fragmentation of the medieval Corpus Christianum, specifically in distinction from tolerance which concerned social and political attitudes. ${ }^{2}$ This governing of diversity was focused on a range of "others" who were not only religiously or socially different, but were further judged as mistaken, wrong, or potentially dangerous in a community. ${ }^{3}$ Toleration was thus associated with a level of power combined with a certain normative or moral dominance. Toleration entailed a long-suffering restraint of governmental force towards these others, whereas other policies could include punishment, exile, or elimination. ${ }^{4}$ Toleration was typically used instrumentally towards a degree of outward conformity of action: levels of toleration tended to be expressed in dynamic layers of visibility or invisibility within a community, as carefully described by historian Benjamin Kaplan. ${ }^{5}$

Particular decisions on toleration tended to be guided by a set of factors. These factors stem from a comparison of late-scholastic conceptions of toleration and literature on governmental practices of early modern toleration. The first factor is the perception of truth and falsehood, which informs understandings of good and evil. ${ }^{6}$ This factor was deeply influenced by contemporary normative standards as typically associated with a particular Church. The factor of truth is secondarily informed by levels of proximity and transience of the alleged evil, the balancing of which determined the measure of long suffering required. ${ }^{7}$ Other factors include perceptions of the common

2. I. P. BeJCZY, "Tolerantia: a medieval concept", Journal of the History of Ideas, July 1997, p. 365-384; B. J. Kaplan, Divided by faith. Religious Conflict and the Practice of Toleration in Early Modern Europe, London, Belknap Press, 2007; E. H. Shagan, The Rule of Moderation: Violence, Religion and the Politics of Restraint in Early Modern England, Cambridge University Press, 2011.

3. I. P. BEJCZY, art. cit., p. 368.

4. J. Costa Lopez, "Beyond Eurocentrism and Orientalism: Revisiting the Othering of Jews and Muslims through medieval canon law", Review of International Studies, July 2016, p. 461.

5. B. J. Kaplan, op.cit., ch. 5-8; Further, J. R. Collins, "Redeeming the Enlightenment: New Histories of Religious Toleration", The Journal of Modern History, 2009, p. 607-636, p. 613.

6. I. P. BEJCZY, art. cit., p. 366.

7. Ibid., p. 371-376. 
good, outward public unity, public order, and economic expediency. ${ }^{8}$ Finally, the degree of mutual social trust informed perceived levels of threat. These factors functioned kaleidoscopically rather than monolithically and could lead in different contexts to different outcomes.

Religious freedom in the context of the liberal constitutional state is normatively and functionally distinct from early modern toleration. Crucially, citizens are principally free as to belief, conscience, and action in matters of religion unless rational and pressing reasons warrant restrictive regulation. Restrictive regulation is further bound by the constraints of the constitutional structure. Equal citizenship further implies that governmental regulation of diversity may not employ the rhetoric of otherness associated with toleration. In France, religious freedom is connected with its commitment to the protection of human rights (Déclaration des droits de l'homme et du citoyen 1789) and laïcité, which encompass the doctrine of the separation of church and state in support and preservation of individual freedom (The 1905 Loi concernant la séparation des Églises et de l'État).

Religious freedom is further embedded in a "secular" liberal constitutional context. Though secularity is understood to be ontologically and morally less prescriptive $^{9}$ compared to religious truth vis-à-vis toleration, power structures ${ }^{10}$ and a measure of tradition-specific normativity ${ }^{11}$ do inform discussions on the rights of religious minorities. Both human rights and laïcité develop dynamically. For example, an absolute separation of church and state was never really enforced under the Third Republic, and several politicians, such as Georges Clemenceau, called for equal access to the public space. ${ }^{12}$ Current

8. Ibid., p. 371-376.

9. L. ZucCA, A Secular Europe: Law and Religion in the European Constitutional Landscape, Oxford University Press, 2012, Chap. 10; as opposed to secularism that is moralising. Compare with the idea of "universalising tendencies" as in E. SHAKMAn Hurd, "The Political Authority of Secularism in International Relations", European Journal of International Relations, 10:2, p. 235-262, p. 237.

10. W. Brown, Regulating Aversion. Tolerance in the Age of Identity and Empire, Princeton University Press, 2006, p. 178.

11. G. D'Costa, "Whose Objectivity, Which Neutrality? The Doomed Quest for a Neutral Vantage Point from Which to Judge Religions", Religious Studies, 29:1, p. 79-95, p. 95; Laïcité and neutrality might be related in the French context, it importantly does not amount to constitutional atheism. See H. Pena-Ruiz, Qu'est-ce que c'est la laïcité ?, Paris, Gallimard 2003, p. 32-40; J.-M. Piret, "La laïcité française: de zuiverheid van het constitutionele ideaal", in P. DE Hert \& K. MeERSChaut, Scheiding van kerk en staat of actief pluralism?, Oxford, Intersentia 2007, p. 131.

12. P. D'Hollander, "The Church in the Street in Nineteenth-Century France", Journal of the Western Society for French History, 2004, p. 189. 
debates on Muslim integration also feature values of individual freedom and laïcité. Yet the meaning of laïcité seems to have evolved to incorporate cultural dimensions, much to the concern of scholars such as Philippe Gaudin and Jean Baubérot. ${ }^{13}$

However, the question of visibility in the open space is no stranger in France's constitutional and democratic state, which was powerfully illustrated by waves of local procession bans in the nineteenth century. The Catholic Church deliberately employed processions to increase its urban visibility and to tangibly underscore its relevance to society in response to rapid social and political changes. ${ }^{14}$ This open encounter caused immediate and explicit tensions on the street. ${ }^{15}$ Some counter-demonstrators argued that syndicalist and political opinions should gain a standing equal to religion, thus advocating in a more inclusive open space. ${ }^{16}$ Several waves of restrictions and bans on processions led to strong popular and political debate - historian Kaiser characterizes this situation as one of "gradual radicalization". ${ }^{17}$ Arguments for restrictions related to 1) allegations over the public nuisance of a procession, 2) a threat to public order because of popular violence, 3) a disguise as a political demonstration, and 4) the idea that public presence somehow was an imposition on all. ${ }^{18}$

This example indicates a set of important questions that appear to be relevant for reflections on the burkini arrêtés: does freedom imply free manifestation in the public space? Is public unity and order maintained by a superficial unity or by inclusive diversity? On what basis could a government legitimately restrict individual freedom and stemming from that, collectively freedom? On what basis are arguments on public order justified? At what point might restrictive regulation become intolerant? These are all questions that relate to the burkini debates as well. Although toleration and religious freedom are distinct concepts, the study of local arrêtés concerning the burkini offers an interesting test case with regards to the connection between

13. J. Baubérot, La laïcité falsifiée, Paris, La Découverte, 2012, p. 39-40; P. Gaudin, "République and laïcité. What is at stake in contemporary France?", Philosophy and social criticism, no. 4-5, 2016, p. 440-447.

14. P. D'Hollander, art. cit., p. 171-172.

15. Ibid., p. 188.

16. Ibid.

17. W. KAISER, “'Clericalism - that is our enemy!': European anticlericalism and the culture wars", in C. CLARK and W. KaIser, Culture wars. Secular-Catholic Conflict in Nineteenth Century Europe, Cambridge University Press, 2003, p. 75-76.

18. P. D'Hollander, art. cit., p. 180. 
the visibility of difference and the currency of the factors related to toleration in the legal argumentation.

\section{THE LANGUAGE OF TOLERATION IN THE 2016 BURKINI ARRÊTÉS}

From July 28 to late August 2016, more than thirty mayors of French (representing mostly coastal communities) banned the burkini as well as the jilbab from beaches for reasons varying from public order and appeals to the principle of laïcité, to public health and the notion of good morality. These arrêtés have reinvigorated debates across France about the compatibility of French and Islamic values. This section will survey the reasoning of several of the local authorities as well as administrative courts dealing with the arrêtés. Herein, the aim is to investigate the resemblance of factors relating to toleration: truth, common good, public order and unity, economic considerations, and trust in the arrêtés of Cannes, Villeneuve-Loubet and Sisco. The arrêtés of Cannes and Villeneuve-Loubet were the earliest and though upheld in a regional court, were the eventually suspended. The Conseil d'État suspended the Villeneuve-Loubet arrêté on 26 August 2016, after which all arrêtés across France were suspended by regional courts, with the exception of the arrêté issued in Sisco.

The arrêtés show a remarkable resonance in their reasoning and language, even though the mayors of the various towns were associated with different political parties. On July 28, 2016, the mayor of Cannes David Lisnard prohibited "ostentatious religious attire" on the public beaches, ${ }^{19}$ but according to the media Nice Matin and Le Monde, he clarified that this referred to the burkini and jilbab only, and not to other religious expressions, such as the kippah or the cross. ${ }^{20}$ Speaking shortly after the Nice-attack of July 2016, he argued that the threat of terrorist attacks would warrant the prohibition of burkinis on the beaches: the burkini would be a sign of religious extremism.

19. "Une tenue de plage manifestant de manière ostentatoire une appartenance religieuse": "Burkini : le maire de Cannes interdit les vêtements religieux à la plage", Le Monde, 11 août 2016: http://www.lemonde.fr/societe/article/2016/08/11/le-maire-de-cannes-interdit-lesvetements-religieux-a-la-plage_4981587_3224.html [accessed 4 June 2018].

20. "Le maire de Cannes interdit le port du burkini sur les plages", Nice matin, 11 août 2016: http://www.nicematin.com/faits-de-societe/le-maire-de-cannes-interdit-le-port-du-burkinisur-les-plages-70612 [accessed 4 June 2018]. "Burkini: le maire de Cannes interdit les vêtements religieux à la plage", Le Monde, 11 août 2016. 
He further framed the arrêté in the context of respecting good morality, laïcité, hygiene and security rules. ${ }^{21}$

The mayor of Villeneuve-Loubet Lionel Luca issued a similar arrêté for the public beaches in his community which is located close to Cannes. On the basis of public order, he prohibited all attire that did not express respect "good morality", "the principle of laïcite", and "hygiene" and "security rules" in the context of the "maritime public domain". ${ }^{22}$ Two mayors on the island of Corsica, Ange-Pierre Vivoni of Sisco and Francis Giudici of Ghisonaccia issued similar arrêtés solely concerned with swimming attire. ${ }^{23}$ Interestingly, the immediate cause for the mayor of Sisco to prohibit burkinis was a riot between youth from the city and North African families in which more than forty people would have been involved. ${ }^{24}$ The mayor suspected that the wearing of ostentatious religious attire could have been a source of serious conflict. ${ }^{25}$

French mayors are competent to issue arrêtés towards public order, which explains the explicit appeal to public order in the text. However, the reasoning in the Villeneuve-Loubet case was scrutinized by the tribunal administratif at Nice upon dispute by the Collectif contre l'islamophobie (CCI) and the Ligue des droits de l'homme (LDH). The court at first affirmed the arrêtés. It argued that, after the Nice attack, these swimming suits could be taken by others as a sign that is not just an expression of religion. The burkini could form a risk for public order. Furthermore, the court judged it to be a proportionate prohibition because of its temporal nature, that is during the month of August. ${ }^{26}$ Yet the court did not specify the exact nature of the risk entailed and what precisely would be expressed by the attire in

21. "L'accès aux plages et à la baignade est interdit [...] à toute personne n'ayant pas une tenue correcte, respectueuse des bonnes mours et de la laïcité, respectant les règles d'hygiène et de sécurité des baignades adaptées au domaine public maritime.", cited on "Burkini: le maire de Cannes interdit les vêtements religieux à la plage", Le Monde, 11 août 2016.

22. Arrêté du 5 août 2016 du maire de la commune de Villeneuve-Loubet, portant règlement de police, de sécurité et d'exploitation des plages concédées par l'État à la commune de Villeneuve-Loubet, no. 2016-42 annule et remplace no. 2016-41, § 4.3.

23. Arrêté du 16 août 2016 du maire de la commune de Sisco, portant interdiction d'accès aux plages et de baignade à toute personne n'ayant pas une tenue correcte. Arrêté no. 2016-37 du 18 août 2016 du maire de la commune de Ghisonaccia, portant interdiction de porter des tenues non correctes, non respectueuses des bonnes mœurs et de la laïcité sur les plages et pour la baignade sur l'ensemble du territoire communal, § 1 .

24. Arrêté du 16 août 2016 du maire de la commune de Sisco.

25. "Considérant que les tenues vestimentaires religieuses ostentatoires peuvent être source de conflit grave [...]": arrêté du 16 août 2016 du maire de la commune de Sisco.

26. TA Nice, 13 août 2016, no. 1603470, § 6; TA Nice, 22 août 2016, no. 1603508, 1603523, $\S 8$. 
question. An appeal followed to the Conseil d'Etat, which ruled against the Villeneuve-Loubet arrêté.

The Conseil d'Etat explained that the argumentation for the arrêté remained insufficient. It judged that there were no tangible risks of terrorism and it found the mere sentiment of fear to be insufficient for warranting an arrêté that limited the fundamental freedoms of citizens this severely. ${ }^{27}$ It also stipulated that other concerns, such as good morality and hygiene could not sustain an arrêté without an apparent risk to the public order. ${ }^{28}$ Following this ruling, the tribunal administratif of Nice suspended the Villeneuve-Loubet arrêté on August 26, 2016, as well as the Cannes arrêté on August 30, 2016. Although the arrêtés were suspended across France, a high number of mayors have been attempting to reinforce their arrêtés nevertheless. The tribunal administratif of Bastia upheld the arrêté of Sisco on the ground of public order because of the actual unrest that had occurred on its beaches. ${ }^{29}$

Upon the decision of the Conseil d'État, the Prime Minister Manual Valls posted a long note on the burkini debate on his Facebook-page. While recognizing that a mayor's power is limited by constitutional law, he went on to argue that the burkini controversy is a multifaceted fight, encompassing cultural and political dimensions. ${ }^{30} \mathrm{He}$ wrote that the burkini is a political sign as much as a religious expression, especially when one considers the limitations it would impose on women's freedom: "Il n'y a pas de liberté qui enferme les femmes!". While he asserted that Muslims are fully part of the French society, he also called for modernization of Islam. According to the Guardian, he previously insisted that the freedom of Muslims should not be restricted, but that political Islam is incompatible with the values of the Republic, especially the principle of laïcité. ${ }^{31}$ Similarly, President Hollande,

27. "En l'absence de tels risques, l'émotion et les inquiétudes résultant des attentats terroristes, et notamment de celui commis à Nice le 14 juillet dernier, ne sauraient suffire à justifier légalement la mesure d'interdiction contestée." and "L'arrêté litigieux a ainsi porté une atteinte grave et manifestement illégale aux libertés fondamentales que sont la liberté d'aller et venir, la liberté de conscience et la liberté personnelle.": CE, ord., 26 août 2016, no. 402742, 402777, § 6 .

28. "Dans ces conditions, le maire ne pouvait, sans excéder ses pouvoirs de police, édicter des dispositions qui interdisent l'accès à la plage et la baignade alors qu'elles ne reposent ni sur des risques avérés de troubles à l'ordre public ni, par ailleurs, sur des motifs d'hygiène ou de décence.": CE, ord., 26 août 2016, no. 402742, 402777, § 6.

29. TA Bastia, 26 janv. 2017, no. 600976, 1600980, § 5.

30. Post Manual Valls, 26 Aug. 2016: https://www.facebook.com/notes/manuel-valls/assumonsle-d\%C3\%A9bat-sur-le-burkini/1125932284153781/ [accessed 4 June 2018].

31. According to The Guardian, A. CHRISAFIS, "French PM supports local bans on burkinis", 18 Aug. 2016: https://www.theguardian.com/world/2016/aug/17/french-pm-supports-localbans-burkinis [accessed 4 June 2018]. 
like many French political figures, expressed that the burkini would be incompatible with French values, but he warned against both provocation and stigmatization. ${ }^{32}$

The political tensions underlying the legal questions concerning the burkini indicate the relevance of the notions of truth, the common good, outward unity, public order, and trust. Firstly, although the language of truth and falsehood might not feature explicitly in the burkini debate, it is clear that significant value judgments are made pertaining to expressions over moral wrong and danger. The dismissal of (orthodox) Islamic values as inherently un-French and arguments about incompatibility with French values, together with expressions about the oppression of women have an effect similar to the notion of truth in the early modern period: these generalize a specific type of Islamic believers as the "other", and further explicitly associates it with something evil. This perhaps follows from a ready conflation of orthodox Islam with political Islam and terrorism. In this way, the burkini is framed as an apparent wrong against which society would need to defend itself.

Secondly, orthodox Islam is discounted from the goods that inform perceptions of the common good. In this regard, the notion of laïcité as one of France's unifying and common goods plays an ambivalent role. While it is, at least historically, intended to protect individual freedom, it is somewhat prone to generalizations regarding religion in the open space that actually limit the freedom it seeks to protect. In this case, laïcité is invoked to justify the ban of religious attire of a specific kind. From the reasoning of the arrêtés, it appears that these were aimed at burkinis even as these texts contained vague and generalized descriptions that could potentially include other types of clothing, but which were explicitly indicated as exempt. Considering the burkini does not cover more than an ordinary hijab, it shows that the seeming neutral language thus ineffectively covers prejudice towards Muslims. These restrictions constituted (in the least) indirect discrimination against a group of Muslim women. Accordingly, even less traditional media mocked the inconsistency of this language featuring a picture of the Chinese "facekini" - used to prevent suntan. ${ }^{33}$

32. According to France24, K. CHHOR, "Both sides of burkini debate cite French commitment to secularism", 3 sept. 2016: http://www.france24.com/en/20160831-france-commitmentsecularism-burkini-ban-debate-laicite [accessed 4 June 2018].

33. According to the Daily Mail, S. DEAN, "Twitter users mock French burkini ban by asking what officials would do if Chinese beachgoers showed up in facekinis", 30 Aug. 2016: http://www.dailymail.co.uk/news/article-3764980/Twitter-users-mock-French-burkiniban-asking-officials-Chinese-beachgoers-showed-facekinis.html [accessed 4 June 2018]. 
Thirdly, the factor of unity is relevant to the burkini controversy insofar the recurring problem of visibility of otherness or even deviance in the open space is concerned. The inconsistent language of religious and political aspects to the burkini is quite curious. This language was also used in the bans on Catholic procession in the nineteenth century. In the latter case, however, it was well understood that individuals retained their religious freedom, whereas individual freedom is crucially at stake in the burkini cases. The conflation of arguments indicates that the issue of ownership regarding open space is really at stake and the language of neutrality typically aims at the exertion of a degree of visible unity. Furthermore, this visible unity might only be superficial since a burkini prohibition would not actually eradicate ideas one perceives as dangerous: the same people still reside together in the same territory. Rather, burkini restrictions are an expression of political symbolism, which reinforce an imagined consensus or a level of outward unity but really veil some of the precarious social tensions from the realm of dialogue.

Fourthly, the factor of public peace and order is the only explicit factor of toleration that is formally shared with the legal logic of religious rights protection. However, the threshold is higher, as only rationally grounded arguments satisfy the requirements of the law. The previous section has shown that most arrêtés, and even the Nice court, failed to qualify this factor beyond the language of fear and security and therefore were scrutinized by the Conseil d'État. It remains unclear what specific threats occurred from the burkini itself and for this reason, a restriction of the burkini appears symbolic - an ineffective measure towards an intangible threat. Further, and fifthly, the question of fear and security is connected with the factor of trust. Both the local arrêtés and the expressions of national politicians exerted a public anxiety about Islamic fundamentalism, perhaps even Islam in general as part of the French society. Such anxiety may be understandable given the series of attacks that have been carried out in France in the name of Daesh and others, and yet, the automatic association of orthodox Islam with terrorism might unhelpfully reinforce the existing divisions of trust where dialogue and rapprochement are needed. The Conseil d'État also dismissed this shallow justification towards the burkini bans.

The Conseil d'État already considered the adjudicated burkini arrêté "une atteinte grave et manifestement illégale aux libertés fondamentales" from a legal perspective. ${ }^{34}$ Now, it appears that this type of restriction had not only

34. CE, ord., 26 août 2016, no. 402742,402777 , § 6 . 
been unlawful, but further substantially relied on the factors associated with early modern toleration: the factors of public peace and order, truth, the common good, unity and trust.

\section{CONCLUSION: INTOLERANCE UNVEILED?}

The unlawfulness of the local burkini arrêtés shows a further and significant liability to the factors of toleration: the factors of truth, common good, outward unity, public order, and trust. Offhand dismissal of Islam by both local and national politicians as "other" and "incompatible" with French values, combined with a casual association with terrorism and a rhetoric of not belonging, is profoundly problematic. Interestingly, and reinforcing the argument of toleration, the crux of the burkini bans has again been the visibility of perceived deviance in the open space. This focus fails to address the underlying social disunity and (worryingly) invigorates the intense existing divisions. Rather, this focus on visibility inherently reinforces the reality of diversity or disintegration that it seeks to level. It highlights the problematic conflation of outward unity and (an imagined) consensus, which was so strongly prevalent in the Corpus Christianum and its aftermath in the early modern period.

Not all aspects of toleration are incompatible with the logic of religious freedom and the French constitutional framework in general. Particularly the factor of public order, as long as argued coherently and rationally, serves structurally in constitutional logic. However, the scope for legitimate uses of the factors of toleration is limited. Moreover, and as the burkini bans have shown, poorly justified uses are liable to restrictive and intolerant tendencies in its historical sense. Given the commonly assumed distinction between toleration and constitutional religious freedom, these cases provide material for reflection on toleration, the matter of visibility, neutrality, and its relationship with individual religious freedom. Beyond legal and political meta-narratives of toleration versus religious freedom, one should be wary of new variations of the burkini bans and all other particular instances of the regulation of political and religious minorities that may exert governmental intolerance, despite seemingly neutral language. Such actions may entail a détournement de pouvoir and as potential instances of regression in toleration need to be fiercely scrutinized with a keen eye to the protection of individual freedom, the rights of minorities, and France's democratic principles. 